\title{
Process optimization of Calophyllum inophyllum-waste cooking oil mixture for biodiesel production using Donax deltoides shells as heterogeneous catalyst
}

\author{
Subramaniapillai Niju*, Govindaraj Vishnupriya and Muthusamy Balajii
}

\begin{abstract}
In the present work, the waste material Donax deltoides shells (DDS) was utilized as a heterogeneous base catalyst for biodiesel production from Calophyllum inophyllum oil (CIO)-waste cooking oil (WCO) mixture. Non-edible CIO possessing $65 \mathrm{mg}$ of $\mathrm{KOH} \mathrm{g}^{-1}$ of acid value was mixed with WCO of low acid value in different proportions. The acid value was reduced to $33.3 \mathrm{mg}$ of $\mathrm{KOH} \mathrm{g}^{-1}$ of oil by using a volumetric ratio of 1:1 and it was further reduced to $5.6 \mathrm{mg}$ of $\mathrm{KOH} \mathrm{g}^{-1}$ of oil by acid catalyzed esterification process and used for biodiesel production. DDS was converted into active $\mathrm{CaO}$ catalyst by calcination and the catalyst characterization was performed using different instrumental techniques. The impact of calcined DDS (catalyst) concentration, reaction time and methanol to esterified oil volumetric ratio on biodiesel conversion was investigated to optimize the transesterification reaction using response surface methodology based central composite design. The biodiesel conversion was determined by proton nuclear magnetic resonance spectroscopy and a maximum biodiesel conversion of $96.5 \%$ was achieved with catalyst concentration of $7.5 \mathrm{wt} \%$, methanol to oil volumetric ratio of $63.8 \%$, reaction time of $129.3 \mathrm{~min}$, stirrer speed of $450 \mathrm{rpm}$ and reaction temperature of $65^{\circ} \mathrm{C}$.
\end{abstract}

Keywords: Calophyllum inophyllum oil, Waste cooking oil, Donax deltoides shells, Esterification, Transesterification, Response surface methodology

\section{Introduction}

World's energy requirement is increasing as industrial, agricultural and transport sectors are dependent on conventional energy resources $[1,2]$. This ever-increasing energy demand was met by utilizing conventional fossil fuel resources which are non-renewable in nature and are getting depleted day by day. In order to overcome the fossil fuel depletion and to meet the growing fuel demands, biofuels can be a better alternative. Biodiesel is one such fuel entails alkyl esters having long chain fatty acids obtained from lipids (oils) or animal fats [3]. In addition, biodiesel is biodegradable, non-toxic, renewable, and sustainable to the environment $[4,5]$. Biodiesel blended with conventional diesel fuel up to $30 \%$ can be directly used in diesel engines irrespective of any major engine alterations [6]. Soybean oil,

\footnotetext{
* Correspondence: sn.bio@psgtech.ac.in

Department of Biotechnology, PSG College of Technology, Coimbatore 641004, India
}

palm oil, and sunflower oil are few edible oils employed for biodiesel production and tested successfully in diesel engines $[7,8]$. Exploiting such edible oils as feedstock leads to food versus fuel conflict and hence, non-edible feedstocks are turned out to be the pin interest for biodiesel production. Non-edible oils such as Moringa oleifera, Jatropha curcas, Croton megalocarpus, Ricinus communis, Pongamia pinnata, Azadirachta indica, Cerbera odllam, Sapium sebiferum, Calophyllum inophyllum were utilized as feedstock for biodiesel production $[9,10]$.

Among the different non-edible feedstocks, C. inophyllum oil (CIO) is the second most cultivated feedstock for biodiesel production [11]. C. inophyllum belongs to the Clusiaceae family and its native range was distributed throughout India. It shows high tolerance to brackish water, salt spray, and winds [12]. An adult plant can grow up to $20-30 \mathrm{~m}$ high. It bears fruits twice a year with the annual production of about 8000 fruits and its kernel 
contains $75 \%$ oil content $[1,7,13,14]$. Hence, CIO can be exploited as a promising resource for the production of biodiesel $[7,15,16]$. Besides, $75-85 \%$ of production cost of biodiesel was attributed to the feedstock $[17,18]$ and hence, it is necessary to produce biodiesel economically. One such inexpensive feedstock is waste cooking oil (WCO) which is available in excess, dumped in landfills and rivers illegally [19]. To manage the WCO disposal problem and to use WCO productively, it can be efficiently employed as biodiesel feedstock. Kulkarni and Dalai [20] reviewed methods of biodiesel production from WCO and discussed quality and performance of methyl esters derived from WCO. Few other researchers also investigated the utilization of WCO as biodiesel feedstocks [19, 21-24].

In general, biodiesel synthesized via transesterification reaction necessitates a catalyst to uphold the reaction [5]. Homogeneous catalysts $(\mathrm{NaOH}$ and $\mathrm{KOH})$ are generally exercised owing to its higher yield under mild reaction conditions and minimum reaction time [25, 26]. Conversely, exploiting such catalysts has numerous problems such as excess wastewater generated during water wash in order to remove the alkaline catalyst from biodiesel [27]. Also, it is difficult to recover the homogeneous catalyst and may corrode the pipelines and reactors. Alternatively, heterogeneous basic catalysts have shown several merits such as non-toxic, low-cost, and eco-friendly nature $[24,28]$. Furthermore, it can be reused, recycled and the product (biodiesel) needs less or no water wash and also produces by-product (glycerol) with high purity $[5,19]$. Hence, heterogeneous catalysts are preferred over homogeneous catalysts. Alkaline earth metal oxides can serve as solid catalyst because of its high basicity and minimal solubility in oil [29]. Calcium oxide $(\mathrm{CaO})$ is one such catalyst which is non-toxic, available naturally, environmental friendly and low solubility in methanol. Utilization of seashells as a heterogeneous catalyst is an economical means of biodiesel production and also serves as an effective waste disposal strategy [5, 30, 31].

Among the various sources, sea shell derived catalyst has an excellent reusability [4]. Recently, $\mathrm{CaO}$ derived from Gallus domesticus shells [22], ostrich egg shell and chicken egg shell [21], waste scallop shell [30], white bivalve clam shell [19], Tellina tenuis [32], river snail shell [5], mussel shell [33], and crab shell [34] has been exploited as heterogeneous catalysts in transesterification process. Donax deltoides shells (DDS) is one such sea shell of bivalve type which is distributed throughout Indo-West Pacific from Andaman and Nicobar Islands to Indonesia and throughout Australia [35].

Process optimization is an important step in the production process to obtain the maximum biodiesel yield and conversion but it is time-devouring and laborious. Response surface methodology (RSM) is a statistical approach to optimize the complex processes which helps to understand the interaction between the process parameters and also minimizes the number of experimental runs essential to obtain maximum conversion and also to acquire adequate data to prove that the result is statistically significant [36-39]. Several authors optimized biodiesel production using RSM techniques [24, 40-43].

The present study aimed to explore the possibility of utilizing DDS as a suitable heterogeneous alkali catalyst for methyl ester (biodiesel) production from CIO-WCO mixture. DDS was converted into the active form of $\mathrm{CaO}$ catalyst via calcination process. The calcined DDS was studied using Fourier Transform Infrared (FTIR) spectroscopy, X-ray Diffraction (XRD), Scanning Electron Microscopy (SEM) and Energy Dispersive Atomic X-ray (EDAX) spectrometry. Optimization of biodiesel process parameters using central composite design (CCD) based RSM was employed to understand the effect of reaction time, calcined DDS concentration and methanol to esterified CIO-WCO oil volumetric ratio on biodiesel conversion. The synthesized biodiesel was analyzed by proton nuclear magnetic resonance spectroscopy $\left({ }^{1} \mathrm{H}-\mathrm{NMR}\right)$ for determining biodiesel conversion.

\section{Materials and methods Materials}

DDS was collected from the sea shore of Mahabalipuram, Chennai. CIO was purchased from Tamil traders, Coimbatore, while WCO was obtained from the canteen, PSG College of Technology, Coimbatore, Tamil Nadu, India. Sulfuric acid $(\geq 97 \%)$, petroleum ether $\left(40-60^{\circ} \mathrm{C}\right)$, and potassium hydroxide $(\geq 85 \%)$ used in the present study were purchased from HiMedia Laboratories Pvt., Mumbai, India, while methanol, ethanol (99.9\%), and phenolphthalein $\mathrm{pH}$ indicator solution were purchased from S.D. Fine Chemicals, Mumbai, India. Acid value of the various oil samples was determined using a standard titration method by titrating $0.1 \mathrm{~N} \mathrm{95 \%} \mathrm{ethanolic} \mathrm{KOH}$ (Burette) solution against the mixture containing $2 \mathrm{~g}$ of oil sample, $30 \mathrm{~mL}$ (equal amounts) of ethanol and petroleum ether mixture, and few drops of phenolphthalein indicator.

\section{Catalyst preparation}

DDS was washed several times with tap water and rinsed with distilled water in order to eliminate the adhered organic impurities. Cleaned DDS was dried in a hot air oven at $105^{\circ} \mathrm{C}$ for $24 \mathrm{~h}$ and were crushed into fine particles and further subjected to calcination at $900{ }^{\circ} \mathrm{C}$ for $3 \mathrm{~h}$ in a programmable muffle furnace. Calcium carbonate $\left(\mathrm{CaCO}_{3}\right)$ present in the raw DDS upon calcination is converted into $\mathrm{CaO}$. The calcined DDS were immediately transferred to a desiccator to avoid contact with air. The schematic workflow for catalyst preparation was shown in Fig. 1. 

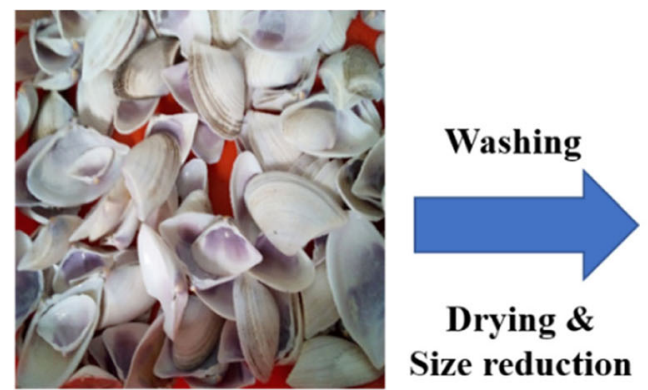

Donax deltoides shells (DDS)

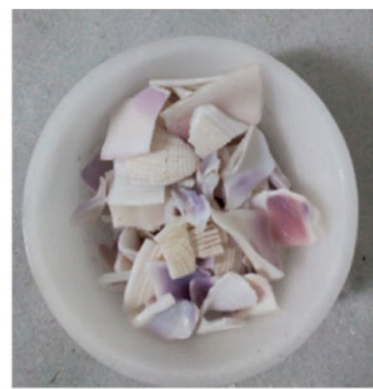

Size reduced DDS

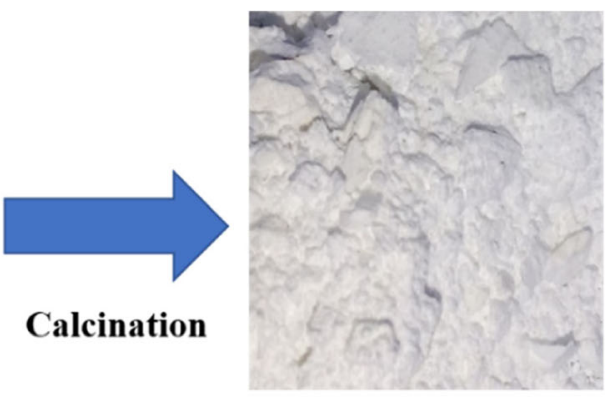

Calcined DDS

Fig. 1 Schematic flow of catalyst preparation

\section{Catalyst characterization}

SEM analysis on a Carl Zeiss (Model: Sigma V) was performed in order to analyze the surface morphology of the uncalcined and calcined DDS. EDAX was done to reveal the elemental composition of the catalyst. Formation of calcium oxide in calcined DDS was confirmed using XRD (Rigaku; Model, DMAX 2200/Ultima C) furnished with $\mathrm{Cu} \mathrm{K \alpha}$ radiation $\left(\mathrm{K}_{\alpha}=1.54 \AA\right)$. XPERT-3 diffractometer system was employed in order to acquire diffraction patterns with the scan range from $2 \theta=10$ to $90^{\circ}$, step size of 0.0130 , step time of $48.19 \mathrm{~s}$ and at the rate of $30 \mathrm{~mA}$ and $45 \mathrm{kV}$. FTIR spectroscopy on ATR-FTIR (Model: BRUKER, Germany) in scan range of $600-4000 \mathrm{~cm}^{-1}$ was accomplished to compare the functional groups present in uncalcined and calcined DDS.

\section{Biodiesel production Esterification}

A two-step esterification-transesterification reaction was employed since the acid value of CIO-WCO mixture was determined as $33.4 \mathrm{mg}$ of $\mathrm{KOH} \mathrm{g}{ }^{-1}$ of oil. Acid value reduction was performed by using $250 \mathrm{~mL}$ three-necked round bottom flask placed in a water bath maintained at $60{ }^{\circ} \mathrm{C}$. After esterification reaction, the acid value of $\mathrm{CIO}-\mathrm{WCO}$ mixture was decreased to $5.6 \mathrm{mg}$ of $\mathrm{KOH} \mathrm{g}{ }^{-1}$ of oil using the optimum esterification conditions of 1:3 methanol to $\mathrm{CIO}-\mathrm{WCO}$ volumetric ratio, $1 \%(\mathrm{v} / \mathrm{v})$ of sulphuric acid, $90 \mathrm{~min}$ of reaction time and stirrer speed of $450 \mathrm{rpm}$. The excess methanol present in the esterified mixture was eliminated by heating and the resulting mixture was allowed to settle for phase separation. The bottom layer containing impurities (water and excess catalyst) was disposed and the top layer was subjected to transesterification reaction.

\section{Transesterification}

Transesterification was performed using a $250 \mathrm{~mL}$ three-necked round bottom flask with a temperature indicator fitted on a side arm and a chilled water condenser fitted on another side arm while mechanical stirrer was inserted in the middle arm. Transesterification reaction was studied to investigate the effect of catalyst concentration, methanol to esterified $\mathrm{CIO}-\mathrm{WCO}$ volumetric ratio and reaction time on methyl ester conversion. For all experimental runs, temperature and stirrer speed was maintained at $65^{\circ} \mathrm{C}$ and $450 \mathrm{rpm}$ respectively. Once the reaction is completed, the transesterified mixture was heated to remove excess methanol followed by filtration using Whatman No. 1 filter paper (Pore size: $11 \mu \mathrm{m}$ ) to remove the catalyst from the reaction mixture. The resulting transesterified mixture was allowed to settle overnight for clear phase separation. High dense bottom layer containing glycerol was discarded whereas the top layer containing fatty acid methyl esters (biodiesel) was examined for biodiesel conversion using ${ }^{1} \mathrm{H}-\mathrm{NMR}$ (Model: Bruker Avance $300 \mathrm{MHz}$ ). $\mathrm{CDCl}_{3}$ was used as a solvent. Percentage biodiesel conversion was determined using the equation given by Knothe [44] as shown in Eq. (1).

$$
\% \text { Biodiesel conversion }=100 * \frac{2 \mathrm{~A}_{\mathrm{ME}}}{3 \mathrm{~A}_{\propto \mathrm{CH} 2}}
$$

where \% Biodiesel conversion is the percentage conversion of $\mathrm{CIO}-\mathrm{WCO}$ to methyl esters, $\mathrm{A}_{\mathrm{ME}}$ is the integration value of the methoxy protons of the methyl esters and $\mathrm{A}_{\alpha \mathrm{CH}_{2}}$ is the integration value of the $\alpha$-methylene protons.

\section{Optimization of the transesterification process Design of experiments}

CCD based RSM was applied to study the impact of three independent transesterification parameters such as calcined DDS concentration, methanol to esterified CIOWCO volumetric ratio and reaction time on biodiesel conversion. The range and levels of the transesterification variables are presented in Table 1. A total of 20 experimental runs were generated with $2^{3}$ factorial 
Table 1 Range and levels of independent variables

\begin{tabular}{llllllll}
\hline Name & Symbols & Units & $(-)$ a & Low & Middle & High & $(+)$ a \\
\hline Catalyst concentration & A & wt\% & 4.64 & 6 & 8 & 10 & 11.36 \\
Methanol to oil ratio & B & $\%(v / v)$ & 55.18 & 62 & 72 & 82 & 88.82 \\
Reaction time & C & Min & 99.55 & 120 & 150 & 180 & 200.45 \\
\hline
\end{tabular}

experiments, 6 axial points, and 6 center points. The effect of independent parameters on biodiesel conversion was analyzed by the second-order polynomial equation as shown in Eq. (2).

$$
\begin{aligned}
\% \text { Biodiesel conversion }=\beta_{0} & +\beta_{1} \mathrm{~A}+\beta_{2} \mathrm{~B}+\beta_{3} \mathrm{C}+\beta_{4} \mathrm{AB} \\
& +\beta_{5} \mathrm{AC}+\beta_{6} \mathrm{BC}+\beta_{7} \mathrm{~A}^{2} \\
& +\beta_{8} \mathrm{~B}^{2}+\beta_{9} \mathrm{C}^{2}
\end{aligned}
$$

where $\mathrm{A}, \mathrm{B}$, and $\mathrm{C}$ are the coded parameters considered for optimization. $\beta_{0}$ represents constant value. The terms $\beta_{1}, \beta_{2}$, and $\beta_{3}$ represent the linear coefficients. The terms $\beta_{4}, \beta_{5}$, and $\beta_{6}$ represent the interaction coefficients with $\beta_{7}, \beta_{8}$, and $\beta_{9}$ representing the quadratic coefficients.

\section{Results and discussion \\ Catalyst characterization}

$X R D$ analysis

XRD pattern of calcined DDS is represented in Fig. 2. The apexes at $2 \theta$ of $32.2,37.4,53.9,64.2,67.4,79.7,88.6^{\circ}$ correspond to $\mathrm{CaO}$. The obtained result shows similarity with calcined angel wing shell [4], obtuse horn shells [25], bivalve clam shells [45], mussel shells [46], golden snail shells [47] and lobster shells [48]. The highly confined intensity peaks of DDS (calcined) represent the $\mathrm{CaO}$ presence and high crystallinity of the sample [33]. Minor peaks at $18.1,34.2,47.2$ and $50.9^{\circ}$ represent the presence of $\mathrm{Ca}$ $(\mathrm{OH})_{2}$ due to the interaction of $\mathrm{CaO}$ with the residual moisture present in the air [30, 45]. Temperature acts a major part in the transformation of $\mathrm{CaCO}_{3}$ to $\mathrm{CaO}$ [25]. The absence of peaks at 26.2, 33.1, 37.8, 45.8, and $52.4^{\circ}$ represents the absence of $\mathrm{CaCO}_{3}$ in calcined DDS which confirms the complete transformation of calcium carbonate to calcium oxide [47].

\section{FTIR analysis}

Figure 3 shows FTIR spectra of DDS (uncalcined and calcined). For uncalcined DDS, distinct peaks were noticed at $707,859,1476$, and $2345 \mathrm{~cm}^{-1}$ while for calcined DDS, the characteristic peaks were identified at $868,1413,1472$, and $3637 \mathrm{~cm}^{-1}$. The absorption band appeared in uncalcined DDS at 707, 859 and $1476 \mathrm{~cm}^{-1}$ indicates the in-plane, out-of-plane vibration and asymmetric stretching modes of $\mathrm{CO}_{3}{ }^{2-}$, respectively [49]. For calcined DDS, the band at

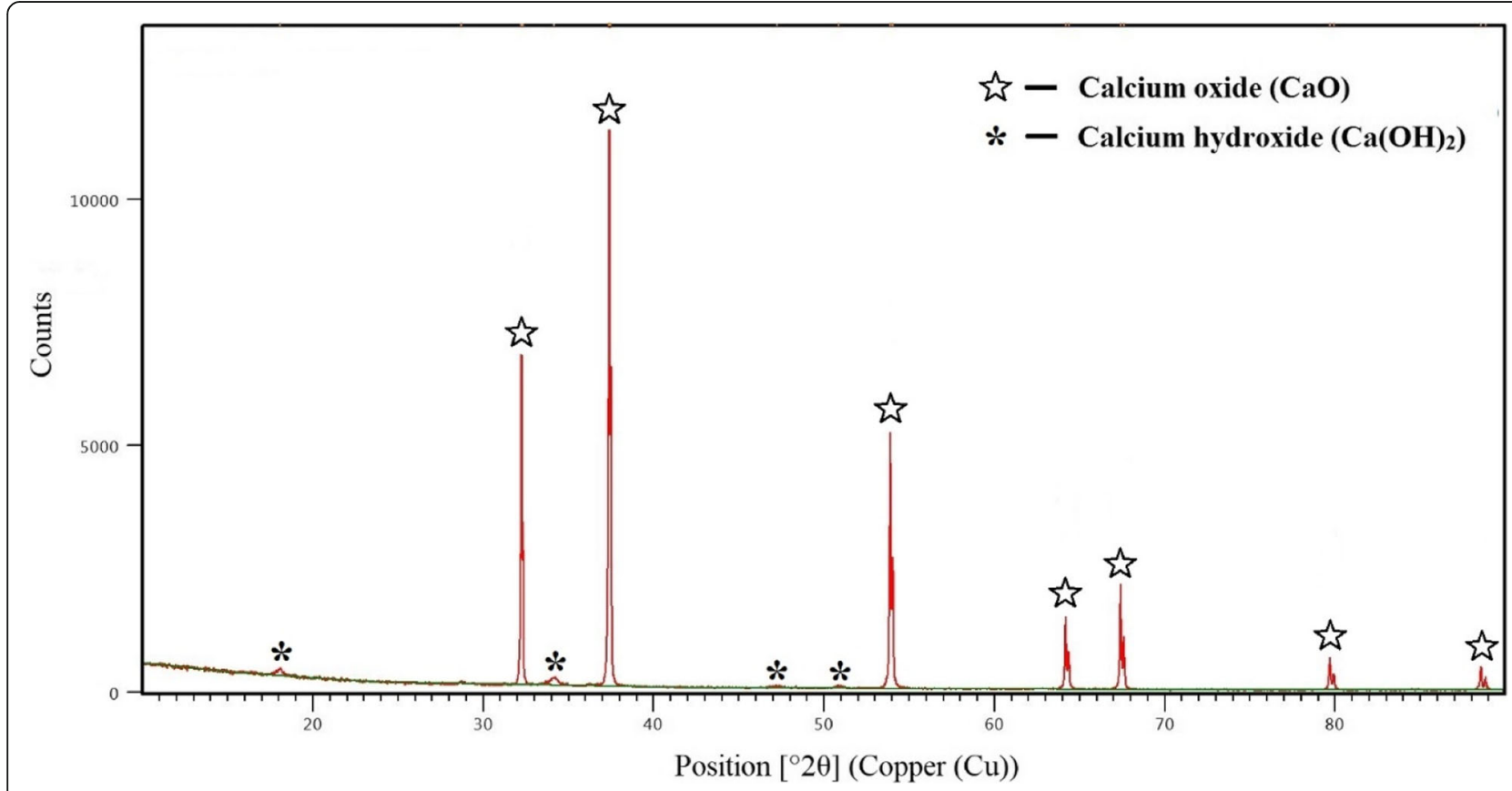

Fig. 2 XRD pattern of calcined DDS 


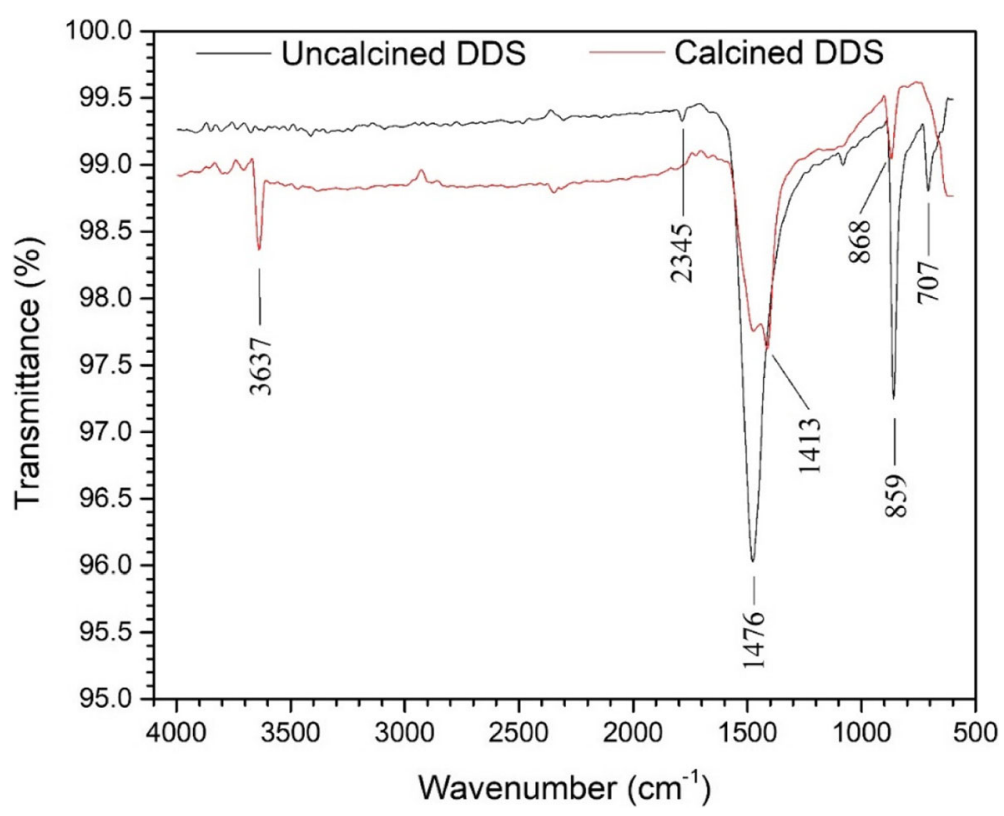

Fig. 3 FTIR spectra of calcined and uncalcined DDS

around $1413 \mathrm{~cm}^{-1}$ represents bending vibration of O-Ca-O group [48] and the band at $868.8 \mathrm{~cm}^{-1}$ for calcined DDS represents shift of $\mathrm{CO}_{3}{ }^{2-}$ molecules to higher energy [45]. The band around $3637 \mathrm{~cm}^{-1}$ in calcined DDS was attributed to $-\mathrm{OH}$ group asymmetric stretching vibration of calcium hydroxide which may arise owing to the interaction of calcined DDS to surrounding air [50].

\section{SEM and EDAX analysis}

Figure $4 \mathrm{a}$ and $\mathrm{b}$ display the surface morphology of uncalcined and calcined DDS. The uncalcined DDS shown in Fig. 4a shows relatively smooth and undistorted flat surface while the calcined DDS illustrated in Fig. 4b shows that particles are highly irregular in shape and are seen as aggregates. Similar morphological changes were reported in obtuse horn shells [25], lobster shells [48], angel wing shell [51], and clam shell [52]. During calcination $\left(900^{\circ} \mathrm{C}-3 \mathrm{~h}\right)$, the undistorted structure of uncalcined DDS transformed into porous clumsy-like structure clearly indicates that calcination at higher temperature is appropriate for complete transformation of $\mathrm{CaCO}_{3}$ to $\mathrm{CaO}$ [51]. Elemental composition of DDS
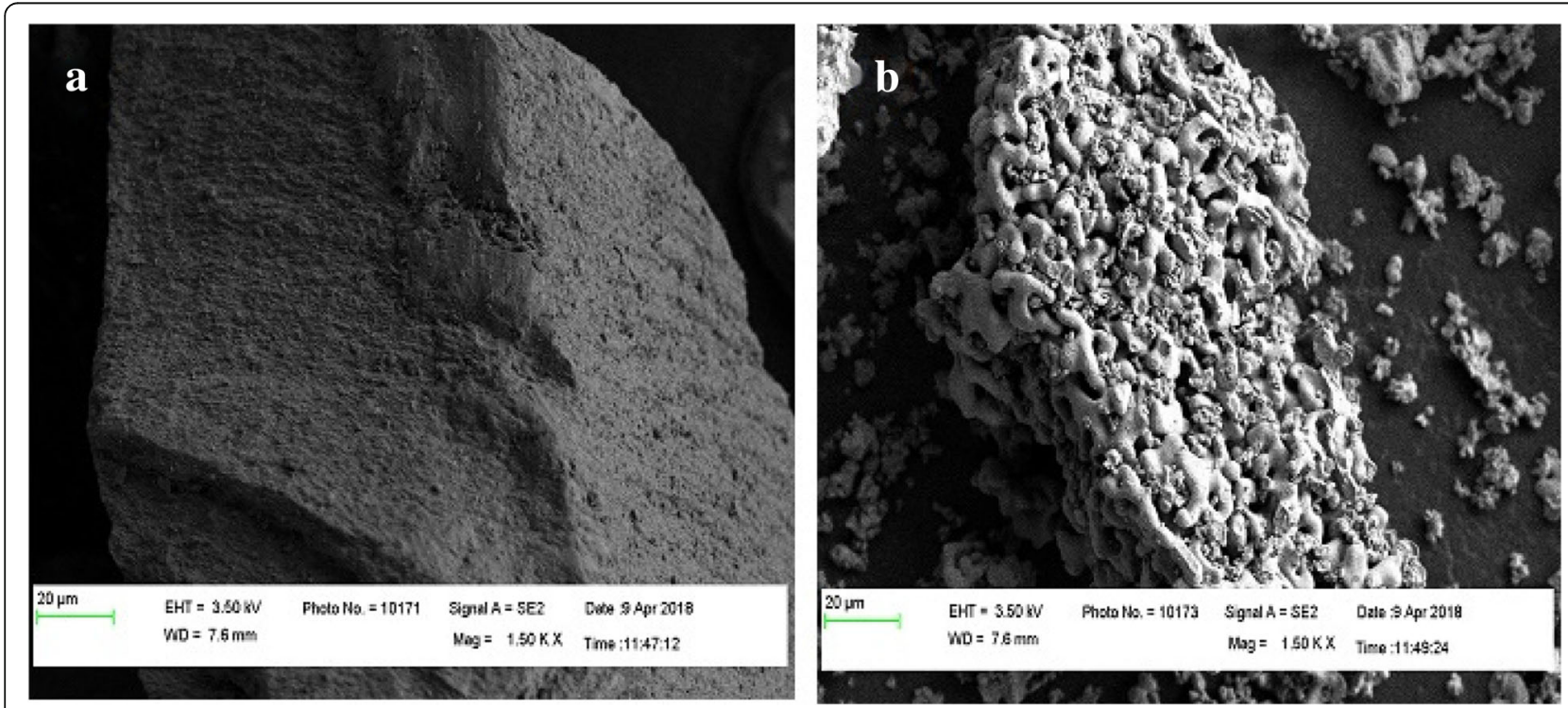

Fig. 4 SEM image of (a) uncalcined DDS and (b) calcined DDS 


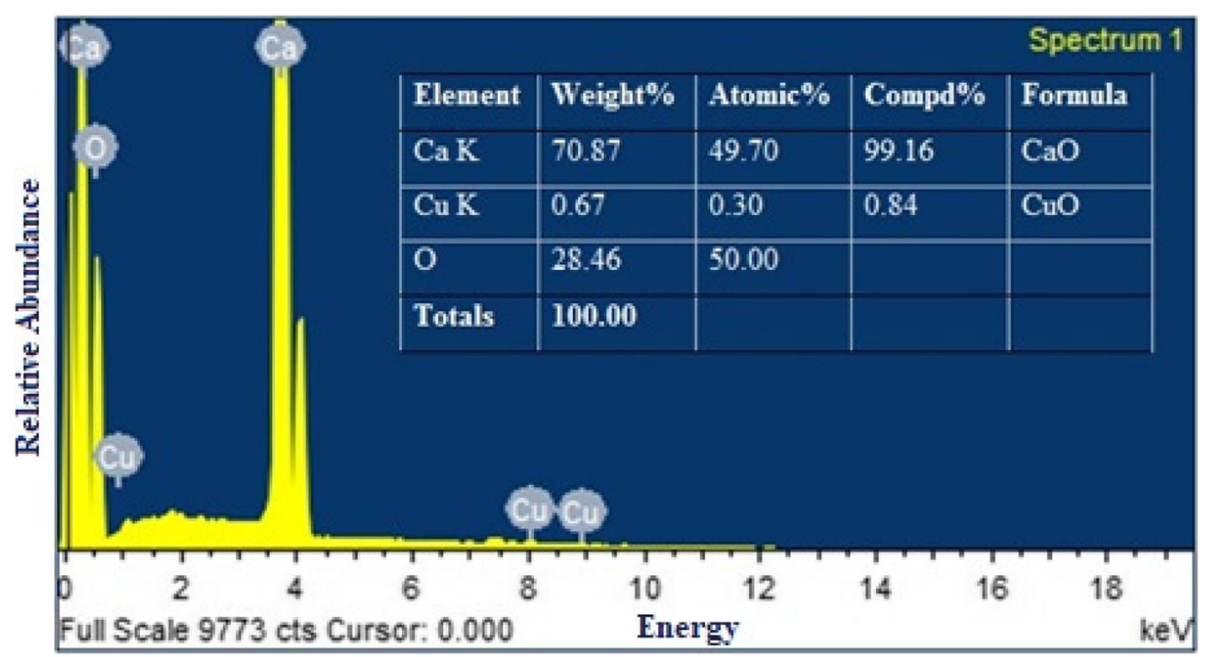

Fig. 5 EDAX analysis of calcined DDS

derived catalyst was analyzed using EDAX with the result presented in Fig. 5. From EDAX, it is evident that calcium is the major component present in the DDS.

\section{Physicochemical properties of $\mathrm{ClO}$ and WCO}

The acid value of the raw $\mathrm{CIO}$ and WCO were determined as $65 \mathrm{mg}$ of $\mathrm{KOH} \mathrm{g} \mathrm{g}^{-1}$ of oil and $0.25 \mathrm{mg}$ of $\mathrm{KOH} \mathrm{g}{ }^{-1}$ of oil respectively. Physicochemical properties of crude WCO and CIO are represented in Table 2. In the present work, methyl ester production via esterification followed by transesterification process was carried out. Different proportions of WCO and CIO were mixed and its corresponding acid value was tabulated (Table 3 ). The acid value of raw CIO:WCO 50:50 v/v was 33.4 $\mathrm{mg}$ of $\mathrm{KOH} \mathrm{g} \mathrm{g}^{-1}$ of oil and was subjected to esterification which reduced the acid value to $5.6 \mathrm{mg}$ of $\mathrm{KOH} \mathrm{g} \mathrm{g}^{-1}$ of oil. Transesterification of esterified mixture further diminishes the acid value to $<0.5 \mathrm{mg}$ of $\mathrm{KOH} \mathrm{g} \mathrm{g}^{-1}$ of oil.

\section{Optimization of biodiesel production}

Central composite design based RSM

To maximize biodiesel conversion through transesterification process and to analyze the relationship between methanol to esterified CIO-WCO volumetric ratio, reaction time and calcined DDS concentration, RSMCCD was employed in this study. Table 4 shows the CCD matrix for the biodiesel production from CIOWCO mixture. The results of CCD were subject to multiple regression analysis initially. It is noticed that the selected model (quadratic) is well suitable for analysis since it is not aliased. ANOVA shown in Table 5 represents that the model is statistically ignificant since it shows smaller $\mathrm{p}$-value and larger $\mathrm{F}$ value. The predicted values are in accordance with experimental values and this emphasizes the better correlation among the input factors and the methyl ester conversion. The predicted $R^{2}=0.9349$ and adjusted $R^{2}=$ 0.9862 shows that the quadratic model is appropriate to predict the biodiesel conversion. The coded equation for methyl ester conversion is presented in Eq. (3).

Table 2 Physicochemical properties and fatty acid composition of $\mathrm{CIO}$ and WCO

\begin{tabular}{llll}
\hline Properties & Waste cooking oil & Calophyllum inophyllum oil & Mixture of WCO and ClO (50-50\%) \\
\hline Acid value $=\left(\mathrm{mg} \mathrm{of} \mathrm{KOH} \mathrm{g}^{-1}\right.$ of oil) & 0.25 & 65 & 33.4 \\
Density at $27^{\circ} \mathrm{C}\left(\mathrm{kg} \mathrm{m}^{-3}\right)$ & 918 & 929 & 922 \\
Kinematic viscosity at $40^{\circ} \mathrm{C}\left(\mathrm{mm}^{2} \mathrm{~s}^{-1}\right)$ & 26.0 & 59.3 & 40.6 \\
Saponification value $\left(\mathrm{mg} \mathrm{of} \mathrm{KOH} \mathrm{g}^{-1}\right)$ & 193 & 382 & 292 \\
Palmitic acid (\%) & 10.1 & 22.3 & 17.1 \\
Oleic acid (\%) & 84.6 & 55.0 & 57.3 \\
Linoleic acid (\%) & - & 17.0 & 15.5 \\
Stearic acid (\%) & - & 4.4 & 4.2 \\
Others (\%) & 5.3 & 1.4 & 6.0 \\
\hline
\end{tabular}


Table 3 Different blends of $\mathrm{CIO}$ and WCO and its corresponding acid values

\begin{tabular}{|c|c|c|c|}
\hline S. No & Calophyllum inophyllum oil (\%) & Waste cooking oil (\%) & Acid value ( $\mathrm{mg}$ of $\mathrm{KOH} \mathrm{g} \mathrm{g}^{-1}$ of oil) \\
\hline 1 & 100 & 0 & 65.0 \\
\hline 2 & 75 & 25 & 44.6 \\
\hline 3 & 50 & 50 & 33.5 \\
\hline 4 & 25 & 75 & 15.4 \\
\hline 5 & 0 & 100 & 0.3 \\
\hline
\end{tabular}

Biodiesel conversion $(\%)=+76.46-3.38 * \mathrm{~A}-10.75$

$$
\begin{aligned}
& * \mathrm{~B}-4.94 * \mathrm{C}-4.56 * \mathrm{AB} \\
& +1.73 * \mathrm{AC}+17.92 \\
& * \mathrm{BC}-15.09 * \mathrm{~A}^{2}-0.0876 \\
& * \mathrm{~B}^{2}-0.9202 * \mathrm{C}^{2}
\end{aligned}
$$

where $\mathrm{A}, \mathrm{B}$, and $\mathrm{C}$ represent the coded forms of DDS concentration (wt\%), methanol to esterified CIOWCO volumetric ratio and reaction time ( $\mathrm{min})$. The term $\mathrm{AB}, \mathrm{AC}$, and $\mathrm{BC}$ represents the interaction terms between the parameters. Terms $A^{2}, B^{2}$, and $C^{2}$ represent the quadratic effects of the independent parameters.

\section{Impact of calcined DDS concentration and methanol to esterified CIO-WCO ratio on methyl ester conversion}

Figure $6 \mathrm{a}$ presents the impact of DDS concentration and methanol to esterified CIO-WCO volumetric ratio on methyl ester production with time being fixed constant as $150 \mathrm{~min}$. Increase in the conversion of oil to methyl esters was perceived with increased catalytic concentration and decreased with increased methanol to esterified CIO-WCO volumetric ratio. The higher amount of DDS enhanced the rate of re-

\begin{tabular}{|c|c|c|c|c|c|}
\hline Run & $\begin{array}{l}\text { A: Catalyst concentration } \\
\text { wt } \%\end{array}$ & $\begin{array}{l}\text { B: Methanol to oil ratio } \\
\%(v / v)\end{array}$ & $\begin{array}{l}\text { C: Reaction time } \\
\text { min }\end{array}$ & $\begin{array}{l}\text { Experimental biodiesel conversion } \\
\%\end{array}$ & $\begin{array}{l}\text { Predicted biodiesel conversion } \\
\%\end{array}$ \\
\hline 1 & 4.64 & 72 & 150 & 38.8 & 39.5 \\
\hline 2 & 8 & 72 & 150 & 76.7 & 76.5 \\
\hline 3 & 6 & 82 & 180 & 67.0 & 68.8 \\
\hline 4 & 11.36 & 72 & 150 & 29.1 & 28.1 \\
\hline 5 & 10 & 62 & 180 & 48.2 & 51.2 \\
\hline 6 & 10 & 82 & 180 & 59.1 & 56.4 \\
\hline 7 & 6 & 82 & 120 & 49.1 & 46.3 \\
\hline 8 & 8 & 72 & 99.6 & 83.0 & 82.2 \\
\hline 9 & 10 & 62 & 120 & 95.0 & 93.4 \\
\hline 10 & 8 & 55.18 & 150 & 95.1 & 94.3 \\
\hline 11 & 6 & 62 & 120 & 91.6 & 94.5 \\
\hline 12 & 8 & 72 & 150 & 76.7 & 76.5 \\
\hline 13 & 10 & 82 & 120 & 23.9 & 27.0 \\
\hline 14 & 8 & 72 & 150 & 76.7 & 76.5 \\
\hline 15 & 8 & 72 & 150 & 76.2 & 76.5 \\
\hline 16 & 8 & 72 & 150 & 75.8 & 76.5 \\
\hline 17 & 8 & 88.82 & 150 & 57.7 & 58.1 \\
\hline 18 & 8 & 72 & 150 & 76.5 & 76.5 \\
\hline 19 & 8 & 72 & 200.5 & 65.0 & 65.6 \\
\hline 20 & 6 & 62 & 180 & 48.2 & 45.3 \\
\hline
\end{tabular}
action and hence higher reaction rate is achieved at a shorter reaction time [21]. At $8 \mathrm{wt} \%$ DDS and $62 \%$

Table 4 CCD matrix for the biodiesel production from CIO-WCO mixture 
Table 5 ANOVA table for transesterification process

\begin{tabular}{|c|c|c|c|c|c|c|}
\hline Source & Sum of Squares & $\mathrm{df}$ & Mean Square & F-value & $p$-value & \\
\hline Model & 8140.50 & 9 & 904.50 & 151.37 & $<0.0001$ & significant \\
\hline A-Catalyst concentration & 155.87 & 1 & 155.87 & 26.09 & 0.0005 & \\
\hline B-Methanol to oil ratio & 1578.11 & 1 & 1578.11 & 264.10 & $<0.0001$ & \\
\hline C-Reaction time & 333.72 & 1 & 333.72 & 55.85 & $<0.0001$ & \\
\hline$A B$ & 166.44 & 1 & 166.44 & 27.85 & 0.0004 & \\
\hline$A C$ & 23.91 & 1 & 23.91 & 4.00 & 0.0734 & \\
\hline BC & 2568.65 & 1 & 2568.65 & 429.87 & $<0.0001$ & \\
\hline$A^{2}$ & 3281.85 & 1 & 3281.85 & 549.23 & $<0.0001$ & \\
\hline$B^{2}$ & 0.1106 & 1 & 0.1106 & 0.0185 & 0.8945 & \\
\hline$c^{2}$ & 12.20 & 1 & 12.20 & 2.04 & 0.1835 & \\
\hline Residual & 59.75 & 10 & 5.98 & & & \\
\hline Lack of Fit & 59.04 & 5 & 11.81 & 82.63 & $<0.0001$ & \\
\hline Pure Error & 0.7145 & 5 & 0.1429 & & & \\
\hline Cor Total & 8200.25 & 19 & & & & \\
\hline
\end{tabular}

$\mathrm{R}^{2}-0.9927$; Adj. $\mathrm{R}^{2}-0.9862 ;$ Pred. $\mathrm{R}^{2}-0.9349$

methanol to esterified $\mathrm{CIO}-\mathrm{WCO}$ volumetric ratio, methyl ester conversion was about $87 \%$. Increasing the volumetric ratio from 62 to $82 \%$ reduced the methyl ester conversion (65\%). This clearly implies that methanol has an inverse relation with biodiesel conversion. Excess methanol leads to difficulty in separation because it increases the glycerol solubility in product phase [37]. Increasing DDS concentration beyond $9 \mathrm{wt} \%$, decreased conversion was found due to the meagre diffusion among oil, methanol and solid DDS phases while using an excess amount of catalyst. A similar trend was reported with $\mathrm{CaO}$ derived from chicken and ostrich egg shells for biodiesel production from WCO [21] and for CIO-WCO mixture using $\mathrm{KOH}$ as a catalyst [53]. From ANOVA table, it was found that the interactive effect between calcined DDS concentration (A) and methanol to esterified CIO-WCO ratio (B) on methyl ester conversion is significant since the p-value (0.0004) was found to be much less than 0.05 .

Impact of calcined DDS concentration and reaction time on methyl ester conversion

Figure $6 \mathrm{~b}$ illustrates the impact of catalyst concentration and reaction time on the conversion of CIOWCO to methyl esters. At $6 \mathrm{wt} \%$ calcined DDS and $120 \mathrm{~min}$ reaction time, methyl ester conversion was found to be $70 \%$. Conversely, a minor decline in conversion $(57 \%)$ was seen when the time was increased to $180 \mathrm{~min}$. Besides, increasing catalyst concentration beyond $8 \mathrm{wt} \%$ and holding the time at $150 \mathrm{~min}$, the methyl ester conversion was around $76 \%$. However, increasing the time resulted in decreased methyl ester conversion (70\%). At $10 \mathrm{wt} \%$ calcined DDS loading and 120 min transesterification time, $60 \%$ conversion was achieved. Furthermore, increasing the transesterification time from 120 to 180 min exhibited decreased conversion (54\%). From the Fig. $6 \mathrm{~b}$, it was observed that between 7 and $8 \mathrm{wt} \%$ of catalyst concentration and transesterification time of 120 min, maximum methyl ester conversion (81\%) was achieved. This clearly indicated that excess reaction time resulted in decreased biodiesel conversion [54]. From ANOVA table, it was observed that the interactive effect between calcined DDS concentration (A) and reaction time (C) on methyl ester conversion is insignificant since the p-value (0.0734) was found to be slightly greater than 0.05 .

\section{Impact of methanol to esterified CIO-WCO oil ratio and reaction time on methyl ester conversion}

Figure 6c represents the impact of methanol to esterified CIO-WCO volumetric ratio and reaction time on methyl ester conversion. At a minimum level of methanol to esterified CIO-WCO volumetric ratio and reaction time, a maximum methyl ester conversion was observed. Besides, increasing the methanol ratio decreases the methyl ester conversion. This clearly indicates that methanol to esterified $\mathrm{CIO}-\mathrm{WCO}$ volumetric ratio has greater impact on methyl ester conversion. Also, the use of excess methanol has a negative impact on biodiesel conversion. Similar observations were reported by Ezekannagha et al. [43] on the transesterification process of lard oil optimized using RSM-CCD. From ANOVA table, it was evident that the interactive effect between methanol to esterified CIO-WCO ratio (B) 

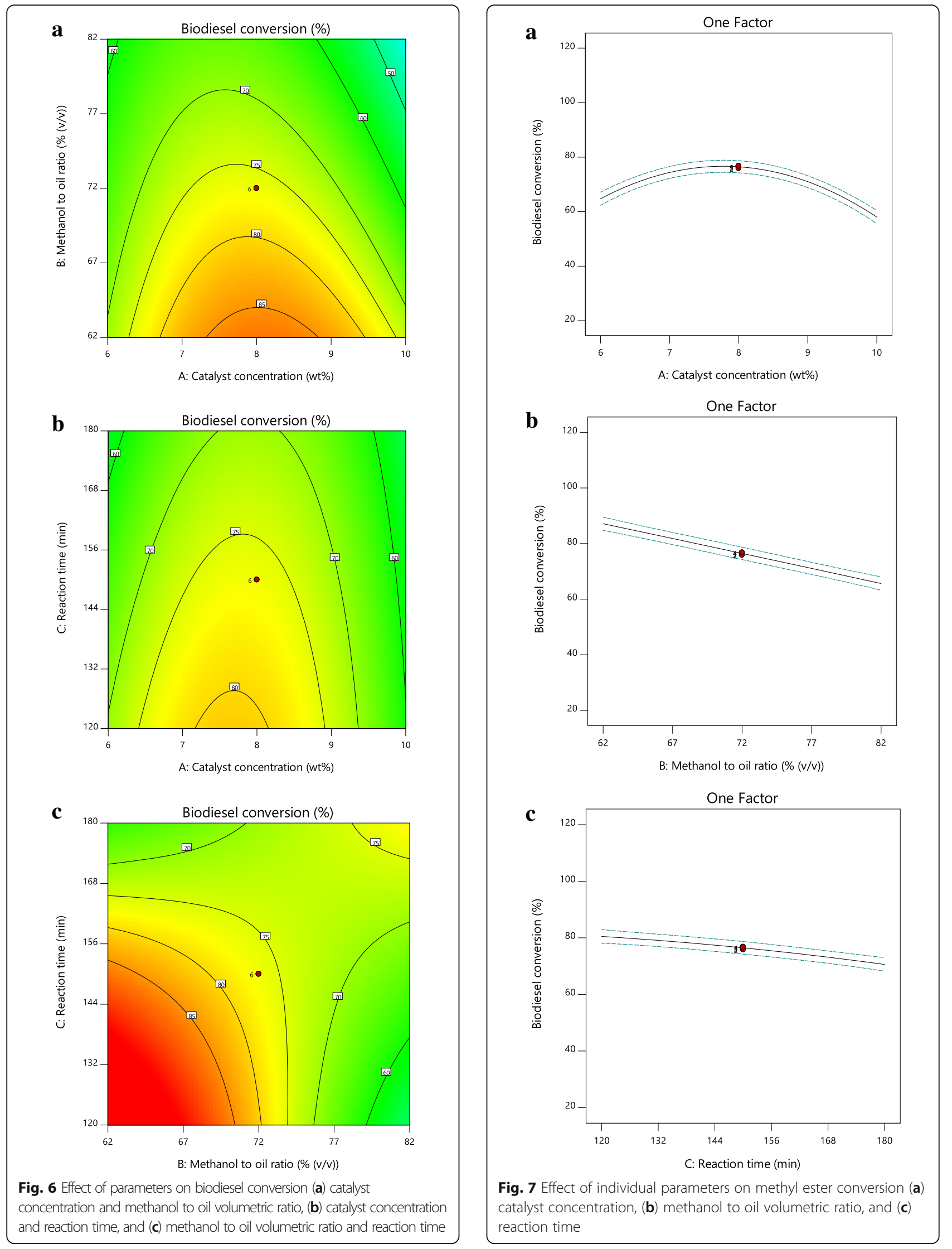
and reaction time $(\mathrm{C})$ on methyl ester conversion is highly statistically significant since the p-value $(<0.0001)$ was found to be very minimum. Furthermore, the graphs presented in Fig. 7a, b and c show the individual parameter effect such as calcined DDS concentration, methanol to esterified $\mathrm{CIO}-\mathrm{WCO}$ ratio, and reaction time on the methyl ester conversion. The synthesized DDS catalyst concentration was varied from 6 to $10 \mathrm{wt} \%$ as shown in Fig. $7 \mathrm{a}$ and it was observed that the catalyst concentration significantly improved the methyl ester conversion up to 8 $w t \%$. Further, increase in the catalyst concentration reduces the methyl ester conversion which can be attributed to the poor mass transfer occurrence in the transesterification reaction due to the high solid loading. However, methanol to oil ratio plays a highly significant role in methyl ester conversion due to its low p-value $(<0.0001)$ and very high F-value (264) followed by reaction time $(\mathrm{p}=0.0001$ and $\mathrm{F}=56)$ and catalyst concentration ( $\mathrm{p}$-value of 0.0005 ).

\section{${ }^{1} \mathrm{H}$-NMR spectrum of ClO-WCO derived methyl esters}

The ${ }^{1} \mathrm{H}$-NMR spectrum of the CIO-WCO derived methyl esters is presented in Fig. 8 and the corresponding biodiesel conversion evaluated by Eq. (1) was determined as $96.5 \%$.

\section{Conclusions}

In the present study, DDS derived $\mathrm{CaO}$ was employed as a cost effective heterogeneous catalyst for methyl esters production from CIO-WCO via transesterification process. Utilizing low-cost $\mathrm{WCO}$ as feedstock makes biodiesel production more economical and also prevents illegal landfilling thereby creating a safe environment. Also, the mixing of WCO with non-edible oil like CIO will act as a potential feedstock owing to the limited prevalence of $\mathrm{CIO}$ throughout the year. Blending of $\mathrm{CIO}$ with WCO at different proportions was evaluated to lower the acid value and the opted CIO-WCO (1:1 volumetric) mixture showed a moderate acid value of 33.4 $\mathrm{mg}$ of $\mathrm{KOH} \mathrm{g}{ }^{-1}$ oil. Further, to diminish the acid value of CIO-WCO mixture, the esterification reaction was executed using sulphuric acid as homogeneous catalyst and the acid value was further decreased to $5.6 \mathrm{mg}$ of $\mathrm{KOH} \mathrm{g} \mathrm{g}^{-1}$ of oil. In transesterification process, the effect of transesterification time, volumetric ratio of methanol to esterified CIO-WCO and calcined DDS concentration on biodiesel conversion was investigated using $\mathrm{CCD}$ of

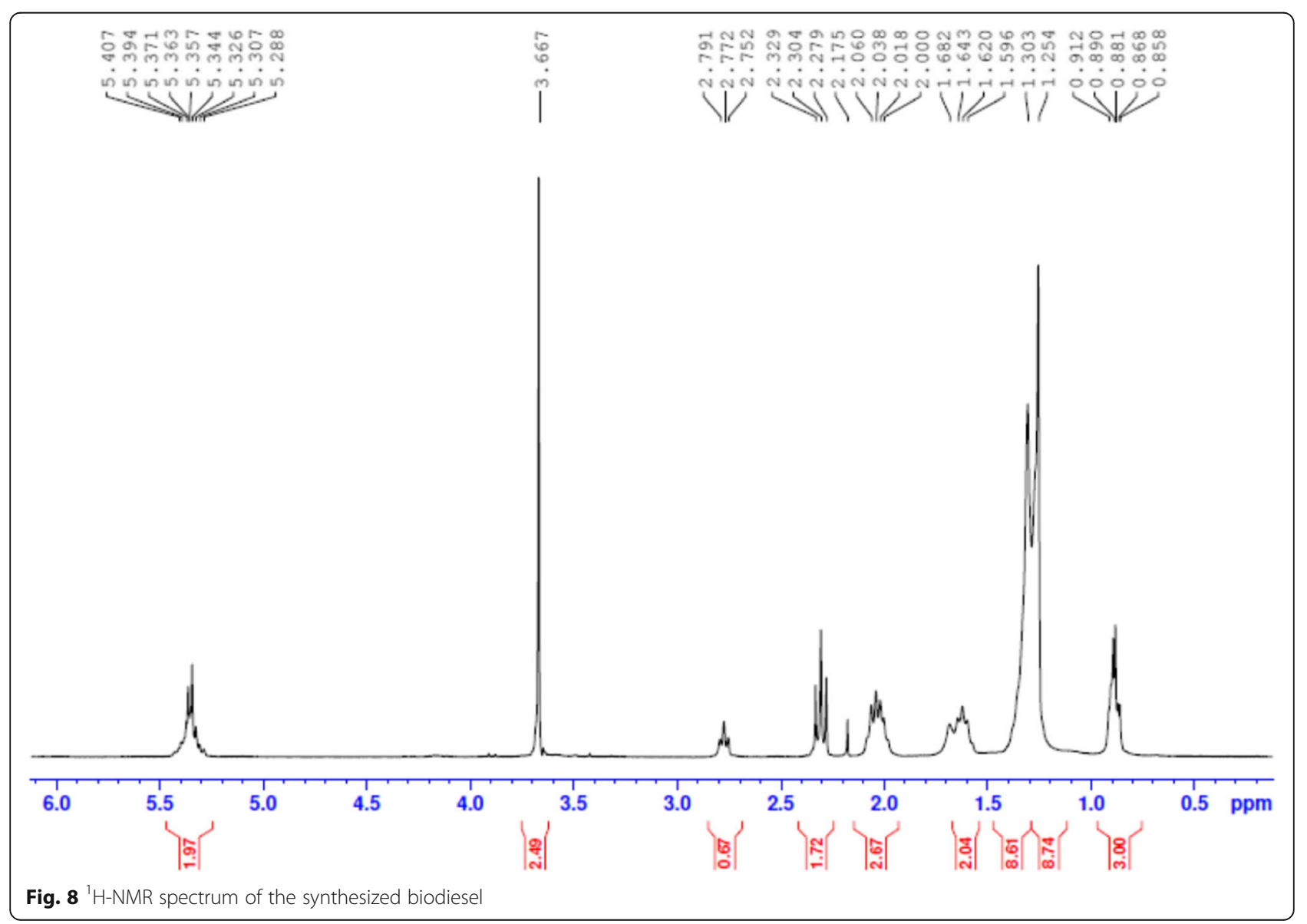


RSM. The ANOVA analysis indicated that the volumetric ratio of methanol to esterified $\mathrm{CIO}-\mathrm{WCO}$ had a greater impact on methyl esters conversion. ${ }^{1} \mathrm{H}-\mathrm{NMR}$ results revealed the maximum experimental methyl esters conversion of $96.5 \%$ at a catalyst concentration of 7.5 $\mathrm{wt} \%$, methanol to esterified (CIO-WCO) oil volumetric ratio of $63.8 \%$, reaction time of $129.3 \mathrm{~min}$, stirrer speed of $450 \mathrm{rpm}$ and transesterification temperature of $65^{\circ} \mathrm{C}$. The observed experimental methyl esters (biodiesel) conversion results were in agreement with the predicted biodiesel conversion of $97.5 \%$.

\section{Acknowledegments}

SN is grateful to Science and Engineering Research Board (SERB), New Delhi, India for Early Career Research Award (ECR) and MB is thankful to SERB for the award of Junior Research Fellowship (JRF).

\section{Authors' contributions}

All authors read and approved the final manuscript.

\section{Competing interests}

The authors declare that they have no competing interests.

\section{Publisher's Note}

Springer Nature remains neutral with regard to jurisdictional claims in published maps and institutional affiliations.

Received: 2 September 2018 Accepted: 21 February 2019

Published online: 06 May 2019

\section{References}

1. Sahoo PK, Das LM, Babu MKG, Naik SN. Biodiesel development from high acid value polanga seed oil and performance evaluation in a $\mathrm{Cl}$ engine. Fuel. 2007:86:448-54

2. Rahman SMA, Masjuki HH, Kalam MA, Abedin MJ, Sanjid A, Sajjad H. Production of palm and Calophyllum inophyllum based biodiesel and investigation of blend performance and exhaust emission in an unmodified diesel engine at high idling conditions. Energ Convers Manage. 2013;76:362-7.

3. Demirbas A. Characterization of biodiesel fuels. Energ Source Part A. 2009; 31:889-96.

4. Syazwani ON, Ibrahim ML, Wahyudiono, Kanda H, Goto M, Taufiq-Yap YH. Esterification of high free fatty acids in supercritical methanol using sulfated angel wing shells as catalyst. J Supercrit Fluid. 2017;124:1-9.

5. Roschat W, Siritanon T, Kaewpuang T, Yoosuk B, Promarak V. Economical and green biodiesel production process using river snail shells-derived heterogeneous catalyst and co-solvent method. Bioresour Technol. 2016; 209:343-50.

6. Mahesh SE, Ramanathan A, Begum KMMS, Narayanan A. Biodiesel production from waste cooking oil using $\mathrm{KBr}$ impregnated $\mathrm{CaO}$ as catalyst. Energ Convers Manage. 2015;91:442-50.

7. Venkanna BK, Reddy CV. Biodiesel production and optimization from Calophyllum inophyllum linn oil (honne oil) - a three stage method. Bioresour Technol. 2009;100:5122-5.

8. Khan TMY, Atabani AE, Badruddin IA, Badarudin A, Khayoond MS Triwahyono S. Recent scenario and technologies to utilize non-edible oils for biodiesel production. Renew Sust Energ Rev. 2014;37:840-51.

9. Atabani AE, César AD. Calophyllum inophyllum L. - a prospective nonedible biodiesel feedstock. Study of biodiesel production, properties, fatty acid composition, blending and engine performance. Renew Sust Energ Rev. 2014:37:644-55.

10. Kathirvelu B, Subramanian S, Govindan N, Santhanam S. Emission characteristics of biodiesel obtained from jatropha seeds and fish wastes in a diesel engine. Sustain Environ Res. 2017:27:283-90.

11. Jain M, Chandrakant U, Orsat V, Raghavan V. A review on assessment of biodiesel production methodologies from Calophyllum inophyllum seed oil. Ind Crop Prod. 2018;114:28-44.
12. Ong HC, Mahlia TMI, Masjuki HH, Norhasyima RS. Comparison of palm oil, Jatropha curcas and Calophyllum inophyllum for biodiesel: a review. Renew Sust Energ Rev. 2011;15:3501-15.

13. Azad AK, Rasul MG, Khan MMK, Sharma SC, Mofijur M, Bhuiya MMK. Prospects, feedstocks and challenges of biodiesel production from beauty leaf oil and castor oil: a nonedible oil sources in Australia. Renew Sust Energ Rev. 2016;61:302-18.

14. Prabakaran K, Britto SJ. Biology, agroforestry and medicinal value of Calophyllum inophyllum L. (Clusiaceae): a review. Int J Nat Prod Res. 2012;1:24-33.

15. Deepalakshmi S, Sivalingam A, Thirumarimurugan M, Sivakumar $P$, Ashokkumar V. Optimization of biodiesel synthesis from Calophyllum inophyllum. Energ Source Part A. 2015;37:2601-8.

16. Fattah IMR, Masjuki HH, Kalam MA, Wakil MA, Ashraful AM, Shahir SA. Experimental investigation of performance and regulated emissions of a diesel engine with Calophyllum inophyllum biodiesel blends accompanied by oxidation inhibitors. Energ Convers Manage. 2014;83:232-40.

17. Siddiquee MN, Rohani S. Lipid extraction and biodiesel production from municipal sewage sludges: a review. Renew Sust Energ Rev. 2011;15:1067-72.

18. Daud NM, Abdullah SRS, Abu Hasan H, Yaakob Z. Production of biodiesel and its wastewater treatment technologies: a review. Process Saf Environ. 2015;94:487-508.

19. Niju S, Begum KMMS, Anantharaman N. Enhancement of biodiesel synthesis over highly active $\mathrm{CaO}$ derived from natural white bivalve clam shell. Arab J Chem. 2016;9:633-9.

20. Kulkarni MG, Dalai AK. Waste cooking oil — an economic source for biodiesel: a review. Ind Eng Chem Res. 2006;45:2901-13.

21. Tan YH, Abdullah MO, Nolasco-Hipolito C, Zauzi NSA. Application of RSM and Taguchi methods for optimizing the transesterification of waste cooking oil catalyzed by solid ostrich and chicken-eggshell derived $\mathrm{CaO}$. Renew Energ. 2017;114:437-47.

22. Mansir N, Teo SH, Rashid U, Taufiq-Yap YH. Efficient waste Gallus domesticus shell derived calcium-based catalyst for biodiesel production. Fuel. 2018;211:67-75.

23. Kawentar WA, Budiman A. Synthesis of biodiesel from second-used cooking oil. Energy Procedia. 2013;32:190-9.

24. El-Gendy NS, Deriase SF, Hamdy A, Abdallah RI. Statistical optimization of biodiesel production from sunflower waste cooking oil using basic heterogeneous biocatalyst prepared from eggshells. Egypt J Petrol. 2015;24:37-48.

25. Lee SL, Wong YC, Tan YP, Yew SY. Transesterification of palm oil to biodiesel by using waste obtuse horn shell-derived $\mathrm{CaO}$ catalyst. Energ Convers Manage. 2015;93:282-8.

26. Abdullah, Sianipar RNR, Ariyani D, Nata IF. Conversion of palm oil sludge to biodiesel using alum and $\mathrm{KOH}$ as catalysts. Sustain Environ Res. 2017:27:291-5.

27. Faroog M, Ramli A, Naeem A. Biodiesel production from low FFA waste cooking oil using heterogeneous catalyst derived from chicken bones. Renew Energ. 2015;76:362-8.

28. Cercado AP, Ballesteros F, Capareda S. Ultrasound assisted transesterification of microalgae using synthesized novel catalyst. Sustain Environ Res. 2018:28:234-9.

29. Gryglewicz S. Rapeseed oil methyl esters preparation using heterogeneous catalysts. Bioresour Technol. 1999:70:249-53.

30. Kouzu M, Kajita A, Fujimori A. Catalytic activity of calcined scallop shell for rapeseed oil transesterification to produce biodiesel. Fuel. 2016;182:220-6.

31. Colombo K, Ender L, Barros AAC. The study of biodiesel production using $\mathrm{CaO}$ as a heterogeneous catalytic reaction. Egypt J Petrol. 2017;26:341-9.

32. Niju S, Indhumathi J, Begum KMMS, Anantharaman N. Tellina tenuis: a highly active environmentally benign catalyst for the transesterification process. Biofuels-UK. 2017;8:565-70.

33. Nurdin S, Rosnan NA, Ghazali NS, Gimbun J, Nour AH, Haron SF. Economical biodiesel fuel synthesis from castor oil using mussel shell-base catalyst (MSBC). Energy Procedia. 2015;79:576-83.

34. Shankar V, Jambulingam R. Waste crab shell derived $\mathrm{CaO}$ impregnated $\mathrm{Na}$ ZSM-5 as a solid base catalyst for the transesterification of neem oil into biodiesel. Sustain Environ Res. 2017;27:273-8.

35. WoRMS. Donax deltoides. Ostend: World Register of Marine Species; 2018.

36. Krishnamurthy KN, Sridhara SN, Kumar CSA. Synthesis and optimization of Hydnocarpus wightiana and dairy waste scum as feed stock for biodiesel production by using response surface methodology. Energy. 2018;153:1073-86.

37. Hamze $H$, Akia M, Yazdani F. Optimization of biodiesel production from the waste cooking oil using response surface methodology. Process Saf Environ. 2015;94:1-10.

38. Jeong GT, Park DH. Optimization of biodiesel production from castor oil using response surface methodology. Appl Biochem Biotech. 2009;156:431-41. 
39. Yuan X, Liu J, Zeng G, Shi J, Tong J, Huang GH. Optimization of conversion of waste rapeseed oil with high FFA to biodiesel using response surface methodology. Renew Energ. 2008;33:1678-84.

40. Dawodu FA, Ayodele OO, Bolanle-Ojo T. Biodiesel production from Sesamum indicum L. seed oil: an optimization study. Egypt J Petrol. 2014;23:191-9.

41. Ajala EO, Aberuagba F, Olaniyan AM, Ajala MA, Sunmonu MO. Optimization of a two stage process for biodiesel production from shea butter using response surface methodology. Egypt J Petrol. 2017;26:943-55.

42. Onukwuli DO, Emembolu LN, Ude CN, Aliozo SO, Menkiti MC. Optimization of biodiesel production from refined cotton seed oil and its characterization. Egypt J Petrol. 2017;26:103-10.

43. Ezekannagha CB, Ude CN, Onukwuli OD. Optimization of the methanolysis of lard oil in the production of biodiesel with response surface methodology. Egypt J Petrol. 2017;26:1001-11.

44. Knothe G. Analyzing biodiesel: standards and other methods. J Am Oil Chem Soc. 2006;83:823-33.

45. Girish N, Niju SP, Begum KMMS, Anantharaman N. Utilization of a cost effective solid catalyst derived from natural white bivalve clam shell for transesterification of waste frying oil. Fuel. 2013;111:653-8.

46. Perea A, Kelly T, Hangun-Balkir Y. Utilization of waste seashells and Camelina sativa oil for biodiesel synthesis. Green Chem Lett Rev. 2016;9:27-32.

47. Margaretha YY, Prastyo HS, Ayucitra A, Ismadji S. Calcium oxide from Pomacea sp. shell as a catalyst for biodiesel production. Int J Energy Environ Eng. 2012;3:33.

48. Hangun-Balkir Y. Green biodiesel synthesis using waste shells as sustainable catalysts with Camelina sativa oil. J Chem-NY. 2016;2016:1-10.

49. Boonyuen S, Smith SM, Malaithong M, Prokaew A, Cherdhirunkorn B, Luengnaruemitchai A. Biodiesel production by a renewable catalyst from calcined Turbo jourdani (Gastropoda: Turbinidae) shells. J Clean Prod. 2018; 177:925-9.

50. Pandit PR, Fulekar MH. Egg shell waste as heterogeneous nanocatalyst for biodiesel production: optimized by response surface methodology. J Environ Manag. 2017;198:319-29.

51. Syazwani ON, Rashid U, Yap YHT. Low-cost solid catalyst derived from waste Cyrtopleura costata (angel wing shell) for biodiesel production using microalgae oil. Energ Convers Manage. 2015;101:749-56.

52. Niju S, Meera KM, Begum S, Anantharaman N. Modification of egg shell and its application in biodiesel production. J Saudi Chem Soc. 2014;18:702-6.

53. Milano J, Ong HC, Masjuki HH, Silitonga AS, Chen WH, Kusumo F, et al. Optimization of biodiesel production by microwave irradiation-assisted transesterification for waste cooking oil - Calophyllum inophyllum oil via response surface methodology. Energ Convers Manage. 2018;158:400-15.

54. Abuhabaya A, Fieldhouse J, Brown D. The optimization of biodiesel production by using response surface methodology and its effect on compression ignition engine. Fuel Process Technol. 2013;113:57-62.

Ready to submit your research? Choose BMC and benefit from:

- fast, convenient online submission

- thorough peer review by experienced researchers in your field

- rapid publication on acceptance

- support for research data, including large and complex data types

- gold Open Access which fosters wider collaboration and increased citations

- maximum visibility for your research: over $100 \mathrm{M}$ website views per year

At $\mathrm{BMC}$, research is always in progress.

Learn more biomedcentral.com/submissions 